-

\title{
Burnout of Older and Younger Employees - The Case of Slovenia
}

\author{
Maja Rožman', Sonja Treven², Vesna Čančer ${ }^{2}$, Marijan Cingula ${ }^{3}$ \\ ${ }^{1}$ Lackova cesta 13, 2000 Maribor, Slovenia \\ maja.500@hotmail.com \\ ${ }^{2}$ University of Maribor, Faculty of Economics and Business, Slovenia \\ sonja.treven@um.si, vesna.cancer@um.si \\ ${ }^{3}$ University of Zagreb, Faculty of Economics and Business, Croatia \\ mcingula@efzg.hr
}

\begin{abstract}
Background and Purpose: People spend a significant part of their lifespan working, but the role of age in job design and implementation of work have largely been ignored. The consequences can be evident in stress and burnout in different symptoms. Thus, age-diverse employees are faced with different symptoms of burnout and stress when carrying out their work. The main aim of this paper is to present burnout of older employees compared to younger employees in Slovenian companies.

Design/Methodology/Approach: The paper is based on research including a survey between two age groups of employees, namely the younger employees that were classified in the group of under 50 years of age and the older employees that were classified in the group of above 50 years of age. Since the Kolmogorov-Smirnov and Shapiro-Wilk test showed that the data was not normally distributed, the noan-parametric Mann-Whitney $U$ test was used to verify differences in the physical symptoms of burnout, emotional symptoms of burnout, and behavioral symptoms of burnout in the workplace between two groups.

Results: The results show that there are significant differences in the great majority of the variables describing the physical symptoms of burnout, emotional symptoms of burnout, and behavioral symptoms of burnout in the workplace between younger and older employees.

Conclusion: Well-being in the workplace of age-diverse employees is a key for long-term effectiveness of organizations. Managers and employers should apply appropriate measures to reduce burnout as well as to contribute to employees well-being and better workplace performance.
\end{abstract}

Keywords: Physical symptoms of burnout, emotional symptoms of burnout, behavioral symptoms of burnout, employees, human resource management

\section{Introduction}

Modern organizations are faced with an important problem: burnout in the workplace and as a result of dissatisfaction and demotivation of their employees in the workplace.

Burnout is an important occupational health issue that has a substantial health and well-being, career progression and organizational productivity impact (Kristensen et al., 2005 in Robinson et al., 2016) and is a psychological re- sponse to prolonged work stress that results from a mismatch between the person and the job (Ellrich, 2016).

Satisfied employees are a vital prerequisite for a healthy company (Halkos and Bousinakis, 2010). Stressful and dissatisfied employees would not be able to deliver the same quality of work and productivity as those employees with lower stress levels and higher satisfaction. Therefore, it is important that employers create a safe and friendly work environment (George and Zakkariya, 2015). Age-related differences are apparent in the nature of stressors 
likely to be encountered at work (Hansson et al., 2001). However, stress can be considered as an unpleasant emotional situation that we experience when requirements (work-related or not) cannot be counter-balanced with our ability to resolve them, which leads to burnout. This results in emotional changes as a reaction to this danger (Halkos and Bousinakis, 2010). Occupational stress and burnout have impacted the health and psychological well-being of workers with the attendant effects on their attitude to work (Brandy and Cox, 2002 in Babajide and Akintayo, 2011). When the working environment is perceived to be conducive, there is less stress and job performance is greatly enhanced (Parkes, 2002).

Burnout refers to a state of emotional and mental exhaustion caused by long-term chronic, emotional, and interpersonal stress while carrying out a task. It is a psychological withdrawal from work in response to excessive stress or dissatisfaction (Leiter et al., 2001). Burnout mediates a relationship between job stressor consisting of role conflict, role ambiguity, and role overload, and job outcomes consisting of job performance, job satisfaction, and turnover intention (Ambrose and Norman, 2010; Fogarty et al., 2000). Intiyas and Supriyadi (2013) clearly suggest that the increase of pressure on the antecedent factor (job stressor) will increase the burnout intensity and then will result in diminished job outcomes.

Burnout of older employees can be explained by a high workload, a lack of challenge and physical demands of the job, less opportunities for growth, and a lack of social support, especially from colleagues within the organization (Henkens and Leenders, 2010).

The consequences of burnout for the individual, for the companies, and for the nation are worrying. Burnout can affect health, giving rise to both physical and psychosomatic problems as well as depression, low self-esteem, guilt feelings, anxiety, and low tolerance for frustration. Work-related consequences can include dissatisfaction with the work, mistakes in the workplace, absenteeism, fluctuation, and presentism (Suner-Soler et al., 2014).

Further, it has become important to understand the role of individual differences in examining the effects of job characteristics on job attitudes (Morgeson and Humphrey, 2006). That means, that job characteristics are not experienced in the same way by all workers (Zaniboni et al., 2014).

Zaniboni et al. (2014) demonstrated that the role of age in the relationship between job characteristics and job attitudes is important, because with the aging population, it is important to see how jobs might be redesigned to enable people to continue to work successfully. It is appropriate to examine the interplay between age and work characteristics because people generally spend a significant part of their lifespan working, and therefore have ample opportunity to display these adaptive processes throughout their working lives, yet the role of age in job design has largely been ignored (Truxillo et al., 2012).

Leaders have an important role in reducing the burden and stress of employees at the workplace by providing adequate complexity of work (Yavas et al., 2013). Despite changes and new directions, organization devote very little focus to safeguard welfare and satisfaction of employees in the workplace. Some companies would not change their practices, even if this would adversely affect the well-being of employees (Rumbles and Rees, 2013).

The main aim of the paper is to consider human resource management in the age-diversity of employees in the context of burnout in the workplace. There is not much literature and research that is comprehensively and systematically based on theoretical knowledge nor studies about age-diverse employees and their symptoms of burnout. With this research we wanted to fill that gap.

First, this article provides a review of the literature on burnout and age-diverse employees. Then the aim of the study and its hypotheses as well as a description of the methodology are discussed. In two following sections the results about the burnout among younger and older employees and discussion of the findings are shown. Finally, limitations and future research opportunities are presented.

\section{Theoretical framework}

\subsection{Symptoms of burnout}

Burnout is a psychological term or concept for the experience of long-term exhaustion and diminished interest, usually in the work context. Further, burnout is often construed as the result of a period of expending too much effort at work while having too little recovery (Embriaco et al., 2007). Burnout symptoms are work-related. High levels of role stress are the result of burnout symptoms (Ashill et al., 2009). Thus, occupational stressors and burnout are serious threats to the health and well-being of employees, which may cause physical, mental and social illness for employees (Mosadeghrad, 2014).

\subsection{Burnout in the workplace}

Burnout in the workplace is a psychological syndrome of chronic emotional and interpersonal stressors experienced by individuals at work and their subsequent responses to the tasks, the organization, co-workers, clients, and themselves. Further, individuals experiencing burnout may suffer from physical illnesses, sleep disturbances, work/ family conflicts, and substance abuse (Swider and Zimmerman, 2010). According to Burke and Greenglass (2001 in Malasch et al. 2001), burnout leads to lower productivity and effectiveness at work. It is associated with decreased job satisfaction and a reduced commitment to the job or the organization. Nahrgang et al. (2011) assert that 
the demands of the workplace have often been linked to increased employee burnout and absenteeism.

Among younger employees the level of burnout is reported to be higher than it is among older employees. Often, age correlates with work experience, so burnout appears to be more of a risk earlier in one's career (Malasch et al. 2001), yet although Finnish research suggested burnout increases with ageing (Ahola et al., 2006 in Henkens and Leenders, 2010). Lester and Brower (2001) pointed out that the effects of stressors are felt more by workers above 45 years than those below forty year of age (Lester and Brower, 2001). According to Henkens and Leenders (2010), burnout of older employees can be explained by a high workload and a lack of challenge and physical demands of the job, less opportunities for growth, and a lack of social support, especially from colleagues.

\subsection{Age-diversity in the workplace}

Demographic changes and age-diversity provide new challenges for the management of organizations (Hertel et al., 2013a). With a more age-diverse workforce, new research questions arise. It becomes more important to find ways for people to stay satisfied and engaged in their work at different life stages (Zaniboni et al., 2014). Organizations' need to know more about age-diversity in the workplace in order to adapt their HRM strategies and leadership styles in an effective and sustainable way for their age-diverse employees (Hertel et al., 2013b). Job characteristics are not experienced in the same way by all age-diverse workers. Given the demographic shifts in today's workplace, worker age would appear to be an important individual difference (Zaniboni et al., 2014). Organizations' should be aware of the well-being of all age-diverse employees, therefore the well-being of employees contributes to the productivity of the organization. It is important to know that a satisfied employee is a necessary precondition for a healthy organization (Halkos and Bossinakis, 2010). Stressful, depressed, and dissatisfied employees cannot achieve the same level of quality of work and productivity than employees with low stress and high satisfaction (George in Zakkariya, 2015).

\subsection{Human resource management}

Human resource management affects the functioning of employees in the organization, while organizations are still insufficiently aware of demographic changes and challenges of an aging workforce for their future development and operation. Ilmarinen (2001) argues that the aging of workforce at a certain level of organization requires consideration of the age of employees in their daily management. The author also stresses that workload must be reduced with age.

\subsection{Age management and diversity man- agement}

Naegele and Walker (2006) define age management as those measures that combat age barriers and promote age-diversity. According to Walker and Taylor (1998 in Principi et al., 2015), age management initiatives may be considered as practices designed to tackle age barriers, either directly or indirectly, and to provide an environment in which each individual is able to achieve his or her potential without being disadvantaged by their age. Thus, age management encompasses the following eight dimensions: job recruitment; learning, training, and lifelong learning; career development; flexible working time practices; health protection and promotion, and workplace design; redeployment; employment exit and the transition to retirement; comprehensive approaches (Naegele and Walker, 2006).

Ashikali and Groeneveld (2015) summarize that diversity management is used to attract, retain, and effectively manage a diverse workforce in order to contribute to the organizations' performance. Thus, diversity management is about changing organizational practices and climates as the only way to realize the potential of a diverse workforce. Managing diversity requires a strategic approach to managing people at work and is an important part of human resource management, which includes a wide range of activities that improve the functioning of individuals and organizations (Beaver and Hutchings, 2005).

\section{Aim of the study and hypotheses}

The main purpose of this research is to examine burnout of employees in the workplace with physical, emotional, and behavioural symptoms in Slovenian companies. This study examines if there are differences in burnout at work settings between younger and older employees. The literature covers all employees, therefore it was decided to investigate if there are differences in burnout between older employees and younger employees.

This paper aims to answer the following research question: (1) RQ1: Are there statistically significant differences in the burnout symptoms in the workplace between older and younger employees?

Based on the research questions were designed three hypotheses in which burnout symptoms are divided into physical symptoms of burnout, emotional symptoms of burnout, and behavioural symptoms of burnout.

The research hypotheses for this study were as follows:

RH1: There are differences in the physical symptoms of burnout in the workplace between older ( 50 to 65 years) and younger employees (18 to 49 years).

In the literature, the definitions of older employees vary. In most cases, the lower age limit defining older em- 
ployees is 45 years (Brooke, 2003) or 50 years (Ilmarinen, 2001). The term "older employees" includes employees between 40 and 50 years of age (Ghosheh et al., 2006). Because of the different theoretical principles, it was decided to use the boundary of 50 years.

Mosadeghrad (2014) argues that job related, individual, organisational, and environmental factors influence employees stress. Further, the job itself including duties, responsibilities, heavy workload, variations in workload, role ambiguity, and role conflict can be a source of stress and burnout for employees in organization. Pruessner et al. (1999) summarize that physical symptoms of burnout include exhaustion, fatigue, headaches, sleep disorders, loss of energy, nonspecific pain, reduced attention span, feelings of meaninglessness, apathy, raised blood pressure, chest pains and gastro-intestinal disorders (Mosadeghrad, 2014).

RH2: There are differences in the emotional symptoms of burnout in the workplace between older ( 50 to 65 years) and younger employees (18 to 49 years).

Burnout is a unique response to continuous and prolonged exposure to occupational stress. Employees who become more tired every day may be more exhausted. Thus, negative emotions are associated with work overload. Further, negative emotions at work play a key role in the development of burnout and they may lead to health deterioration. Burnout is saturated with low-arousal and unpleasant emotions (Beata et al., 2014). Emotional symptoms of burnout in the workplace may include depressed mood states, anxiety, irritability, loss of confidence, tension, or sadness (Mosadeghrad, 2014).

RH3: There are differences in the behavioural symptoms of burnout in the workplace between older (50 to 65 years) and younger employees (18 to 49 years).

Burnout leads to lower productivity and effectiveness at work. It is associated with decreased job satisfaction and a reduced commitment to the job or the organization (Maslach et al., 2001). Behavioral symptoms of burnout in the workplace may include disturbed sleep patterns, reduced reaction times, reduced work capacity, and less work motivation (Mosadeghrad, 2014).

\section{Methodology}

\subsection{Data and sample}

The quantitative method of data gathering was used in the empirical study to examine the burnout in the workplace between younger and older employees, including physical, emotional, and behavioral symptoms of burnout. Questionnaires were sent to small, medium-sized, and large Slovenian companies in January 2016. This research includes 400 companies and one employee in each company. The companies were from basic industries, capital goods, consumer durables, consumer non-durables, consumer services, finance, healthcare, miscellaneous, public utilities, technology, and transportation. The sampling frame included companies from business register AJPES, which had registered 191.863 companies in 2015. From those companies, 525 companies were randomly selected with the program Random Number Generator and the response rate was $76 \%$. The respondent in each company was selected by the company itself randomly, after receiveing the questionnaire. The employees were divided into two age groups, namely the younger employees were classified in the group of under 50 years of age and the older employees were classified in the group of above 50 years of age. The sample consists of 400 employees: 174 (43.5\%) young employees (18 to 49 years) and 226 (56.5\%) older employees (50 to 65 years). The Level of the highest achieved education of the respondents includes: $2(0.5 \%)$ Primary school, 64 (16.0\%) Vocational or secondary school, 137 (34.3\%) High school, 180 (45.0\%) University education, and $17(4.2 \%)$ Masters degree or doctorate. The respondents were from all regions in Slovenia. The Size of companies in which the respondents are employed includes: $102(25.5 \%)$ large companies, $226(56.5 \%)$ medium-sized companies, and $72(18 \%)$ small companies.

\subsection{Research instrument}

When designing the questionnaire for measuring the burnout of employees in the workplace, we relied on various theoretical principles and research. Physical symptoms of burnout in the workplace have been summarized based on Shirom's (1989) categories. Emotional symptoms of burnout in the workplace have been summarized using Yunus and Mahajar (2009), Michael et al. (2009) and Moore (2000) listings. Behavioral symptoms of burnout in the workplace have been summarized referencing Fairbrother and Warn (2003); Grebner et al. (2010) and Malik et al. (2010).

To determine the burnout of older and younger employees in the workplace, the employees indicated their agreement to the listed statements on a 5-point Likert type scale labelled from 1 to 5 whereby 1 is strongly disagree and 5 is completely agree.

\subsection{Statistical analysis}

In article arithmetic means and medians to describe the symptoms of burnout of younger and older employees were used. The Kolmogorov-Smirnov and Shapiro-Wilk test were used to verify the normality of the data distribution (Bastič, 2006). We found that the data is not normally distributed, therefore, we have verified the differences between younger and older employees with the non-parametric Mann-Whitney U test (which is a substitute for the par- 
ametric t-test of independent samples). The Mann-Whitney $\mathrm{U}$ test is based on the average ranks and sums of ranks (Bastič, 2006) of answers about the physical, emotional, and behavioural symptoms of burnout.

\section{Results}

The Kolmogorov-Smirnov and Shapiro-Wilk test showed that data is not normally distributed $(p<0.001)$ at a $0.1 \%$ significance level (Bastič, 2006) for any statement that describe the burnout of employees, therefore, the differences between two independent samples were examined with the non-parametric Mann-Whitney U test.

Table 1 presents descriptive statistics for the symptoms of burnout of employees in the workplace. In Table 2 , the arithmetic mean and the median of the statements according to the age groups are shown. Table 3 presents the average ranks and sums of ranks for answers about the physical symptoms of burnout of younger and older employees on which the Mann-Whitney U test is based. They are shown to facilitate the understanding of the test results. To implement this test, the values of the numeric variable are converted into ranks. This means that Mann-Whitney $\mathrm{U}$ test numeric variable are converted into ranks, therefore value rankings are used for test statistic. Table 4 presents statistically significant differences in physical symptoms of burnout between younger and older employees.

The results in Table 1 show that employees are faced with physical, emotional and behavioral symptoms of burnout in the workplace. In the context of physical symptoms, employees are more susceptible to headaches and migraines, messy sleep cycle, tiredness and exhaustioness, lower back pain and shoulder pain. In the context of emotional symptoms, employees are more susceptible to tension and in the context of behavioral symptoms and more susceptible to insomnia.

The arithmetic means and the medians for answers about the physical symptoms of younger and older respondents in Table 2 show that on average physical symptoms in our sample are more common at older respondents. Table 2 shows that the means for answers about the physical symptoms of younger and older respondents indicate that, on average, older respondents had the highest agreement with: I have headaches, migraines; I have lower back pain, shoulder pain; I often have the flu or virosis; I have increased heart rate; I have stomach aches; my blood pressure varies; I have indigestion; I have sweaty and cold hands; I have vertigo; I'm sweating.

On average higher agreement of younger respondents is achieved with the following statements describing physical symptoms: I am often tired, exhausted; my sleep cycle is messy.

The review of average ranks in Table 3 shows that significant differences in the physical symptoms of burnout exists between the groups. This is reflected in headaches, migraines; messy sleep cycle; vertigo; sweating; sweaty and cold hands; blood pressure varies; flu or virosis; tiredness; stomach aches; increased heart rate; lower back pain, shoulder pain and in indigestion.

Table 4 presents the results of the Mann-Whitney U test for considering statistically significant differences in the physical symptoms of burnout among older and younger employees.

The results of the Mann-Whitney $U$ test in Table 4 show that the differences are statistically significant $(p$ $<0.001$ ) at a $0.1 \%$ significance level in most (i.e. $67 \%$ ) variables of physical symptoms of burnout. These statements are: I have vertigo (tsi3); I'm sweating (tsi4); I have sweaty and cold hands (tsi5); My blood pressure varies (tsi6); I often have the flu or virosis (tsi7); I have stomach aches (tsi9); I have increased heart rate (tsi10); I have indigestion (tsi12).

Based on this result, we accepted hypothesis RH1: There are significant differences in the physical symptoms of burnout in the workplace between older (50 to 65 years) and younger (18 to 49 years) employees.

In the following tables we will present the results for the second research hypothesis.

Further, in Table 5, the arithmetic mean and the median of the age groups are shown. Table 6 presents the average ranks and sums of ranks for answers about the emotional symptoms of burnout of younger and older employees on which the Mann-Whitney U test is based. Table 7 presents statistically significant differences in emotional symptoms of burnout between younger and older employees.

The arithmetic means and the medians for answers about the emotional burnout of younger and older employees in Table 5 show that on average both of them are not emotional burnout. On average, younger employees are more tense than older employees.

The review of average ranks in Table 6 shows that significant differences in the emotional symptoms of burnout exist between the groups. This is reflected in depressive feelings, tension, panic, afraid of losing the job or not finishing the work on schedule, sadness, feeling of helplessness, everything seems meaningless, emotionally exhausted, exceedingly sensitive, quarrelsome and in anger.

Table 7 represents the results of the Mann-Whitney $\mathrm{U}$ test for considering statistically significant differences in the emotional symptoms of burnout among older and younger employees.

By using the Mann-Whitney U test, we verified whether the observed differences are statistically significant. Results of the Mann-Whitney $U$ test in Table 7 show that the differences are statistically significant $(\mathrm{p}<0.001)$ at a $0.1 \%$ significance level in most (i.e. $73 \%$ ) statements. These statements are: I am tense (csi2); I feel panic (csi3); I am afraid of losing the job or not finishing the work on schedule (csi4); I am sad (csi5); I have a feeling of helplessness (csi6); To me, everything seems meaningless 
Table 1: Descriptive statistics for answers about the symptoms of burnout in the workplace

\begin{tabular}{|c|c|c|c|c|c|}
\hline & $\mathbf{N}$ & Mean & $\begin{array}{c}\text { Std. } \\
\text { Deviation }\end{array}$ & Minimum & Maximum \\
\hline tsi1: I have headaches, migraines. & 400 & 3,36 &, 810 & 1 & 5 \\
\hline tsi2: My sleep cycle is messy. & 399 & 3,47 & ,879 & 1 & 5 \\
\hline tsi3: I have vertigo. & 400 & 1,68 & ,644 & 1 & 4 \\
\hline tsi4: I'm sweating & 399 & 1,78 & ,696 & 1 & 4 \\
\hline tsi5: I have sweaty and cold hands. & 398 & 1,84 & ,733 & 1 & 4 \\
\hline tsi6: My blood pressure varies. & 399 & 1,88 & ,833 & 1 & 4 \\
\hline tsi7: I often have the flu or virosis. & 399 & 2,88 & ,904 & 1 & 5 \\
\hline tsi8: I am often tired, exhausted. & 400 & 3,53 & ,928 & 1 & 5 \\
\hline tsi9: I have stomach aches. & 399 & 2,01 & ,845 & 1 & 4 \\
\hline tsi10: I have increased heart rate & 400 & 2,13 & ,960 & 1 & 5 \\
\hline tsi11: I have lower back pain, shoulder pain. & 398 & 3,24 & 1,084 & 1 & 5 \\
\hline tsi12: I have indigestion. & 398 & 1,72 & ,693 & 1 & 5 \\
\hline csi1: I have depressive feelings. & 400 & 2,60 & 867 & 1 & 5 \\
\hline csi2: I am tense. & 399 & 3,34 & 1,024 & 1 & 5 \\
\hline csi3: I feel panic & 399 & 1,89 & ,725 & 1 & 5 \\
\hline $\begin{array}{c}\text { csi4: I am afraid of losing the job or not finishing the } \\
\text { work on schedule. }\end{array}$ & 399 & 2,52 & ,896 & 1 & 5 \\
\hline csi5: I am sad. & 400 & 2,11 & ,842 & 1 & 5 \\
\hline csi6: I have a feeling of helplessness. & 400 & 1,86 & ,719 & 1 & 5 \\
\hline csi7: To me, everything seems meaningless. & 399 & 1,79 & ,693 & 1 & 5 \\
\hline csi8: I am emotionally exhausted. & 400 & 2,64 & ,899 & 1 & 5 \\
\hline csi9: I am exceedingly sensitive. & 400 & 2,09 & ,816 & 1 & 5 \\
\hline csi10: I am quarrelsome. & 400 & 2,12 & ,731 & 1 & 4 \\
\hline csi11: I feel anger. & 400 & 2,10 & ,738 & 1 & 4 \\
\hline vsi1: I have attacks of rage and cry. & 400 & 1,97 &, 705 & 1 & 4 \\
\hline vsi2: I avoid activities. & 400 & 2,64 & ,885 & 1 & 5 \\
\hline vsi3: I have nightmares. & 400 & 2,40 & ,885 & 1 & 5 \\
\hline vsi4: I have insomnia. & 399 & 3,00 & 999 & 1 & 5 \\
\hline vsi5: I have difficulties with concentration and memory. & 399 & 1,87 & ,744 & 1 & 4 \\
\hline vsi6: I wish for solitude. & 399 & 1,94 & ,768 & 1 & 5 \\
\hline vsi7: My working ability has declined. & 399 & 2,23 & ,921 & 1 & 5 \\
\hline vsi8: I lack the will to work. & 400 & 2,71 & 1,062 & 1 & 5 \\
\hline vsi9: I lack the will to socialise with co-workers. & 399 & 2,65 & 1,018 & 1 & 5 \\
\hline
\end{tabular}


Table 2: The arithmetic means and the medians for answers about the physical symptoms of younger and older employees

\begin{tabular}{|c|c|c|c|c|c|c|}
\hline & \multicolumn{2}{|c|}{18 to 49 years } & \multicolumn{2}{|c|}{50 to 65 years } & \multicolumn{2}{c|}{ Total } \\
\hline & Mean & Median & Mean & Median & Mean & Median \\
\hline tsi1: I have headaches, migraines. & 3.32 & 3.00 & 3.38 & 4.00 & 3.36 & 3.00 \\
\hline tsi2: My sleep cycle is messy. & 3.50 & 4.00 & 3.44 & 4.00 & 3.47 & 4.00 \\
\hline tsi3: I have vertigo. & 1.29 & 1.00 & 1.97 & 2.00 & 1.68 & 2.00 \\
\hline tsi4: I'm sweating & 1.53 & 1.00 & 1.97 & 2.00 & 1.78 & 2.00 \\
\hline tsi5: I have sweaty and cold hands. & 1.61 & 1.00 & 2.02 & 2.00 & 1.84 & 2.00 \\
\hline tsi6: My blood pressure varies & 1.58 & 1.00 & 2.11 & 2.00 & 1.88 & 2.00 \\
\hline tsi7: I often have the flu or virosis. & 2.66 & 3.00 & 3.04 & 3.00 & 2.88 & 3.00 \\
\hline tsi8: I am often tired, exhausted. & 3.60 & 4.00 & 3.47 & 4.00 & 3.53 & 4.00 \\
\hline tsi9: I have stomach aches. & 1.70 & 1.00 & 2.25 & 2.00 & 2.01 & 2.00 \\
\hline tsi10: I have increased heart rate & 1.79 & 1.00 & 2.40 & 2.00 & 2.13 & 2.00 \\
\hline tsi11: I have lower back pain, shoulder pain. & 3.21 & 3.00 & 3.27 & 4.00 & 3.24 & 3.00 \\
\hline tsi12: I have indigestion. & 1.31 & 1.00 & 2.03 & 2.00 & 1.72 & 2.00 \\
\hline
\end{tabular}

(csi7); I am emotionally exhausted (csi8); I am exceedingly sensitive (csi9). Based on this results, we can answer the research question that there are statistically significant differences in the emotional symptoms of burnout between older and younger employees.

Based on the results, we accepted hypothesis RH2: There are significant differences in the emotional symptoms of burnout in the workplace between older (50 to 65 years) and younger (18 to 49 years) employees.

In the following tables we will present the results for the third research hypothesis.

In Table 8, the arithmetic mean and the median of the age groups are shown. Table 9 presents the average ranks and sums of ranks for answers about the behavioral symptoms of burnout of younger and older employees on which the Mann-Whitney U test is based. Table 10 presents statistically significant differences in behavioral symptoms of burnout between younger and older employees.

The arithmetic means and the medians for answers about the behavioural burnout of younger and older employees in Table 8 show that older respondents are more susceptible to behavioural symptoms of burnout than younger respondents. On average, higher values of agreement of older respondents is achieved with the following statements describing behavioural symptoms of burnout: I lack the will to socialise with co-workers; I lack the will to work; I avoid activities; my working ability has declined; I have nightmares. On average, older respondents are neither agree nor disagree with these statements.
On average, younger respondents have the next lowest symptoms of burnout: I have difficulties with concentration and memory; I wish for solitude and my working ability has declined, while the mean value indicates a higher burnout symptom of which is: I have insomnia.

The review of average ranks in Table 9 shows that significant differences in the behavioural symptoms of burnout exist between the groups. Which is reflected in attacks of rage and cry, avoid activities, nightmares, insomnia, difficulties with concentration and memory, wish for solitude, declined working ability, lack will to work, lack will to socialise with co-workers.

Table 10 represents the results of the Mann-Whitney $\mathrm{U}$ test for considering statistically significant differences in the behavioral symptoms of burnout among older and younger employees.

The results of the Mann-Whitney $U$ test in Table 10 shows that differences are statistically significant $(\mathrm{p}<$ 0.001 ) at $0.1 \%$ significance level in most (i.e. $89 \%$ ) variables of behavioural symptoms of burnout. These statements are: I have attacks of rage and cry (vsi1); I avoid activities (vsi2); I have nightmares (vsi3); I have difficulties with concentration and memory (vsi5); I wish for solitude (vsi6); my working ability has declined (vsi7); I lack the will to work (vsi8); I lack the will to socialise with co-workers (vsi9).

Based on this results, we accepted hypothesis RH3: There are significant differences in the behavioral symptoms of burnout in the workplace between older (50 to 65 years) and younger (18 to 49 years) employees. 
Table 3: Average ranks and sums of ranks for answers about the physical symptoms of burnout of younger and older employees

\begin{tabular}{|c|c|c|c|c|}
\hline & & $\mathbf{N}$ & Mean Rank & $\begin{array}{l}\text { Sum of } \\
\text { Ranks }\end{array}$ \\
\hline \multirow[t]{3}{*}{ tsi1: I have headaches, migraines. } & 18 to 49 years & 174 & 192.56 & 33505.50 \\
\hline & 50 to 65 years & 226 & 206.61 & 46694.50 \\
\hline & Total & 400 & & \\
\hline \multirow[t]{3}{*}{ tsi2: My sleep cycle is messy. } & 18 to 49 years & 173 & 200.97 & 34768.00 \\
\hline & 50 to 65 years & 226 & 199.26 & 45032.00 \\
\hline & Total & 399 & & \\
\hline \multirow[t]{3}{*}{ tsi3: I have vertigo. } & 18 to 49 years & 174 & 132.59 & 23071.00 \\
\hline & 50 to 65 years & 226 & 252.78 & 57129.00 \\
\hline & Total & 400 & & \\
\hline \multirow[t]{3}{*}{ tsi4: I'm sweating. } & 18 to 49 years & 173 & 154.16 & 26670.00 \\
\hline & 50 to 65 years & 226 & 235.09 & 53130.00 \\
\hline & Total & 399 & & \\
\hline \multirow[t]{3}{*}{ tsi5: I have sweaty and cold hands. } & 18 to 49 years & 174 & 159.14 & 27690.50 \\
\hline & 50 to 65 years & 224 & 230.85 & 51710.50 \\
\hline & Total & 398 & & \\
\hline \multirow[t]{3}{*}{ tsi6: My blood pressure varies. } & 18 to 49 years & 174 & 151.88 & 26426.50 \\
\hline & 50 to 65 years & 225 & 237.22 & 53373.50 \\
\hline & Total & 399 & & \\
\hline \multirow[t]{3}{*}{ tsi7: I often have the flu or virosis. } & 18 to 49 years & 173 & 177.82 & 30763.50 \\
\hline & 50 to 65 years & 226 & 216.98 & 49036.50 \\
\hline & Total & 399 & & \\
\hline \multirow[t]{3}{*}{ tsi8: I am often tired, exhausted. } & 18 to 49 years & 174 & 205.67 & 35787.00 \\
\hline & 50 to 65 years & 226 & 196.52 & 44413.00 \\
\hline & Total & 400 & & \\
\hline \multirow[t]{3}{*}{ tsi9: I have stomach aches. } & 18 to 49 years & 174 & 156.29 & 27195.00 \\
\hline & 50 do 65 years & 225 & 233.80 & 52605.00 \\
\hline & Total & 399 & & \\
\hline \multirow[t]{3}{*}{ tsi10: I have increased heart rate. } & 18 to 49 years & 174 & 156.61 & 27250.50 \\
\hline & 50 to 65 years & 226 & 234.29 & 52949.50 \\
\hline & Total & 400 & & \\
\hline \multirow[t]{3}{*}{ tsi11: I have lower back pain, shoulder pain. } & 18 to 49 years & 173 & 196.78 & 34042.50 \\
\hline & 50 to 65 years & 225 & 201.59 & 45358.50 \\
\hline & Total & 398 & & \\
\hline \multirow[t]{3}{*}{ tsi12: I have indigestion. } & 18 to 49 years & 174 & 131.62 & 22902.50 \\
\hline & 50 to 65 years & 224 & 252.23 & 56498.50 \\
\hline & Total & 398 & & \\
\hline
\end{tabular}


Table 4: Statistically significant differences in physical symptoms of burnout between younger and older employees

\begin{tabular}{|c|c|c|}
\hline & Mann-Whitney U & Asymp. Sig. (2-tailed) \\
\hline tsi1: I have headaches, migraines. & 18280.500 & .195 \\
\hline tsi2: My sleep cycle is messy. & 19381.000 & .874 \\
\hline tsi3: I have vertigo. & 7846.000 & .000 \\
\hline tsi4: I'm sweating & 11619.000 & .000 \\
\hline tsi5: I have sweaty and cold hands. & 12465.500 & .000 \\
\hline tsi6: My blood pressure varies. & 11201.500 & .000 \\
\hline tsi7: I often have the flu or virosis. & 15712.500 & .000 \\
\hline tsi8: I am often tired, exhausted. & 18762.000 & .404 \\
\hline tsi9: I have stomach aches. & 11970.000 & .000 \\
\hline tsi10: I have increased heart rate. & 12025.500 & .000 \\
\hline tsi11: I have lower back pain, shoulder pain. & 18991.500 & .667 \\
\hline tsi12: I have indigestion. & 7677.500 & .000 \\
\hline
\end{tabular}

Table 5: The arithmetic means and the medians for answers about the emotional symptoms of burnout of younger and older employees

\begin{tabular}{|c|c|c|c|c|c|c|}
\hline & \multicolumn{2}{|c|}{18 to 49 years } & \multicolumn{2}{|c|}{50 to 65 years } & \multicolumn{2}{c|}{ Total } \\
\hline & Mean & Median & Mean & $\begin{array}{c}\text { Me- } \\
\text { dian }\end{array}$ & Mean & $\begin{array}{c}\text { Me- } \\
\text { dian }\end{array}$ \\
\hline csi1: I have depressive feelings. & 2.60 & 3.00 & 2.60 & 2.00 & 2.60 & 3.00 \\
\hline csi2: I am tense. & 3.76 & 4.00 & 3.01 & 3.00 & 3.34 & 3.00 \\
\hline csi3: I feel panic & 1.68 & 1.00 & 2.05 & 2.00 & 1.89 & 2.00 \\
\hline $\begin{array}{c}\text { csi4: I am afraid of losing the job or not } \\
\text { finishing the work on schedule. }\end{array}$ & 2.98 & 3.00 & 2.16 & 2.00 & 2.52 & 2.00 \\
\hline csi5: I am sad. & 1.82 & 2.00 & 2.34 & 2.00 & 2.11 & 2.00 \\
\hline csi6: I have a feeling of helplessness. & 1.51 & 1.00 & 2.13 & 2.00 & 1.86 & 2.00 \\
\hline csi7: To me, everything seems meaningless. & 1.36 & 1.00 & 2.12 & 2.00 & 1.79 & 2.00 \\
\hline csi8: I am emotionally exhausted. & 2.70 & 3.00 & 2.59 & 2.00 & 2.64 & 3.00 \\
\hline csi9: I am exceedingly sensitive. & 1.87 & 2.00 & 2.26 & 2.00 & 2.09 & 2.00 \\
\hline csi10: I am quarrelsome. & 2.16 & 2.00 & 2.09 & 2.00 & 2.12 & 2.00 \\
\hline csi11: I feel anger. & 2.12 & 2.00 & 2.08 & 2.00 & 2.10 & 2.00 \\
\hline
\end{tabular}

\section{Discussion and conclusion}

We answered the research question with the results of the Mann-Whitney test that show: there are statistically significant differences in the burnout symptoms in the workplace between younger and older employees in Slovenian companies.

The results of this research show that on average, older employees are more susceptible to physical symptoms of burnout than younger employees. This is reflected in headaches and migraines, lower back pain and shoulder pain, flu or virosis, increased heart rate, stomach aches, blood pressure varies, indigestion, sweaty and cold hands, vertigo and sweating. Thus, long-term health problems and chronic diseases increase with age. Older employees need urgent adjustments at work due to their health problems to prevent the risks of early retirement and work disability. Lower physical capacity is mainly a problem at jobs 
Table 6: Average ranks and sums of ranks for answers about the emotional symptoms of burnout of younger and older employees

\begin{tabular}{|c|c|c|c|c|}
\hline & & $\mathbf{N}$ & $\begin{array}{l}\text { Mean } \\
\text { Rank }\end{array}$ & $\begin{array}{l}\text { Sum of } \\
\text { Ranks }\end{array}$ \\
\hline \multirow[t]{3}{*}{ csi1: I have depressive feelings. } & 18 to 49 years & 174 & 206.50 & 35931.00 \\
\hline & 50 to 65 years & 226 & 195.88 & 44269.00 \\
\hline & Total & 400 & & \\
\hline \multirow[t]{3}{*}{ csi2: I am tense. } & 18 to 49 years & 174 & 246.51 & 42892.50 \\
\hline & 50 to 65 years & 225 & 164.03 & 36907.50 \\
\hline & Total & 399 & & \\
\hline \multirow[t]{3}{*}{ csi3: I feel panic. } & 18 to 49 years & 174 & 160.07 & 27851.50 \\
\hline & 50 to 65 years & 225 & 230.88 & 51948.50 \\
\hline & Total & 399 & & \\
\hline \multirow[t]{3}{*}{$\begin{array}{l}\text { csi4: I am afraid of losing the job or not finishing the work } \\
\text { on schedule. }\end{array}$} & 18 to 49 years & 174 & 258.16 & 44920.00 \\
\hline & 50 to 65 years & 225 & 155.02 & 34880.00 \\
\hline & Total & 399 & & \\
\hline \multirow[t]{3}{*}{ csi5: I am sad. } & 18 to 49 years & 174 & 162.17 & 28218.00 \\
\hline & 50 to 65 years & 226 & 230.01 & 51982.00 \\
\hline & Total & 400 & & \\
\hline \multirow[t]{3}{*}{ csi6: I have a feeling of helplessness. } & 18 to 49 years & 174 & 143.78 & 25018.00 \\
\hline & 50 to 65 years & 226 & 244.17 & 55182.00 \\
\hline & Total & 400 & & \\
\hline \multirow[t]{3}{*}{ csi7: To me, everything seems meaningless. } & 18 to 49 years & 174 & 129.07 & 22458.50 \\
\hline & 50 to 65 years & 225 & 254.85 & 57341.50 \\
\hline & Total & 399 & & \\
\hline \multirow[t]{3}{*}{ csi8: I am emotionally exhausted. } & 18 to 49 years & 174 & 213.53 & 37154.00 \\
\hline & 50 to 65 years & 226 & 190.47 & 43046.00 \\
\hline & Total & 400 & & \\
\hline \multirow[t]{3}{*}{ csi9: I am exceedingly sensitive. } & 18 to 49 years & 174 & 167.86 & 29207.50 \\
\hline & 50 to 65 years & 226 & 225.63 & 50992.50 \\
\hline & Total & 400 & & \\
\hline \multirow[t]{3}{*}{ csi10: I am quarrelsome. } & 18 to 49 years & 174 & 207.75 & 36148.50 \\
\hline & 50 to 65 years & 226 & 194.92 & 44051.50 \\
\hline & Total & 400 & & \\
\hline \multirow[t]{3}{*}{ csi11: I feel anger. } & 18 to 49 years & 174 & 204.08 & 35510.50 \\
\hline & 50 to 65 years & 226 & 197.74 & 44689.50 \\
\hline & Total & 400 & & \\
\hline
\end{tabular}


Table 7: Statistically significant differences in the emotional symptoms of burnout between younger and older employees

\begin{tabular}{|c|c|c|}
\hline & Mann-Whitney U & Asymp. Sig. (2-tailed) \\
\hline csi1: I have depressive feelings. & 18618.000 & .334 \\
\hline csi2: I am tense. & 11482.500 & .000 \\
\hline csi3: I feel panic. & 12626.500 & .000 \\
\hline csi4: I am afraid of losing the job or not finishing \\
the work on schedule. & 9455.000 & .000 \\
\hline csi5: I am sad. & 12993.000 & .000 \\
\hline csi6: I have a feeling of helplessness. & 9793.000 & .000 \\
\hline csi7: To me, everything seems meaningless. & 7233.500 & .000 \\
\hline csi8: I am emotionally exhausted. & 17395.000 & .037 \\
\hline csi9: I am exceedingly sensitive. & 13982.500 & .000 \\
\hline csi10: I am quarrelsome. & 18400.500 & .230 \\
\hline csi11: I feel anger. & 19038.500 & .550 \\
\hline
\end{tabular}

Table 8: The arithmetic means and the medians for answers about the behavioral symptoms of burnout of younger and older employees

\begin{tabular}{|c|c|c|}
\hline & Mann-Whitney U & Asymp. Sig. (2-tailed) \\
\hline csi1: I have depressive feelings. & 18618.000 & .334 \\
\hline csi2: I am tense. & 11482.500 & .000 \\
\hline csi3: I feel panic. & 12626.500 & .000 \\
\hline $\begin{array}{c}\text { csi4: I am afraid of losing the job or not finishing the work } \\
\text { on schedule. }\end{array}$ & 9455.000 & .000 \\
\hline csi5: I am sad. & 12993.000 & .000 \\
\hline csi6: I have a feeling of helplessness. & 9793.000 & .000 \\
\hline csi7: To me, everything seems meaningless. & 7233.500 & .000 \\
\hline csi8: I am emotionally exhausted. & 17395.000 & .037 \\
\hline csi9: I am exceedingly sensitive. & 13982.500 & .000 \\
\hline csi10: I am quarrelsome. & 18400.500 & .230 \\
\hline csi11: I feel anger. & 19038.500 & .550 \\
\hline
\end{tabular}

with high physical workload. Satisfactory employment and friendly working environment can help age-diverse employees to avoid sickness and physical deterioration, secure good cognitive and physical capacity and promote positive and active attitudes towards life.

Although the results show that older employees on average disagree with the statements describing emotional burnout, average values of their agreement are higher in the case of feeling panic, being said, having a feeling of helplessness, meaningless and being exceedingly sensitive. Physical symptoms and emotional symptoms of burnout may be related to discriminatory and stereotyped treatment of older employees in the workplace. Older employees often have difficulties in the case of educa- tion, training, remuneration, promotion within the workplace since they are treated differently than younger employees. Usually, employers only see obligation in older employees rather than using them as a valuable resource since they have a lot of knowledge and experience. Age discrimination, prejudices and stereotypes about age by the employers have a significant negative impact on the working environment, well-being and state of health of the older employees. Younger employees often suffer from an imbalance between work and private life; therefore, they often experience stress or fail to complete their work on schedule. Younger employees are faced with tension within a workplace or when carrying out work tasks, they do not have so much professional experience and expertise as 
Table 9: Average ranks and sums of ranks for answers about the behavioral symptoms of burnout of younger and older employees

\begin{tabular}{|c|c|c|c|c|}
\hline & & $\mathbf{N}$ & $\begin{array}{l}\text { Mean } \\
\text { Rank }\end{array}$ & $\begin{array}{l}\text { Sum of } \\
\text { Ranks }\end{array}$ \\
\hline \multirow[t]{3}{*}{ vsi1: I have attacks of rage and cry. } & 18 to 49 years & 174 & 172.25 & 29972.00 \\
\hline & 50 to 65 years & 226 & 222.25 & 50228.00 \\
\hline & Total & 400 & & \\
\hline \multirow[t]{3}{*}{ vsi2: I avoid activities. } & 18 to 49 years & 174 & 175.30 & 30503.00 \\
\hline & 50 to 65 years & 226 & 219.90 & 49697.00 \\
\hline & Total & 400 & & \\
\hline \multirow[t]{3}{*}{ vsi3: I have nightmares. } & 18 to 49 years & 174 & 175.89 & 30604.50 \\
\hline & 50 to 65 years & 226 & 219.45 & 49595.50 \\
\hline & Total & 400 & & \\
\hline \multirow[t]{3}{*}{ vsi4: I have insomnia. } & 18 to 49 years & 173 & 213.92 & 37007.50 \\
\hline & 50 to 65 years & 226 & 189.35 & 42792.50 \\
\hline & Total & 399 & & \\
\hline \multirow[t]{3}{*}{ vsi5: I have difficulties with concentration and memory. } & 18 to 49 years & 174 & 135.31 & 23543.50 \\
\hline & 50 to 65 years & 225 & 250.03 & 56256.50 \\
\hline & Total & 399 & & \\
\hline \multirow[t]{3}{*}{ vsi6: I wish for solitude. } & 18 to 49 years & 173 & 139.18 & 24078.50 \\
\hline & 50 to 65 years & 226 & 246.56 & 55721.50 \\
\hline & Total & 399 & & \\
\hline \multirow[t]{3}{*}{ vsi7: My working ability has declined. } & 18 to 49 years & 174 & 134.99 & 23488.50 \\
\hline & 50 to 65 years & 225 & 250.27 & 56311.50 \\
\hline & Total & 399 & & \\
\hline \multirow[t]{3}{*}{ vsi8: I lack the will to work. } & 18 to 49 years & 174 & 163.64 & 28474.00 \\
\hline & 50 to 65 years & 226 & 228.88 & 51726.00 \\
\hline & Total & 400 & & \\
\hline \multirow[t]{3}{*}{ vsi9: I lack the will to socialise with co-workers. } & 18 to 49 years & 174 & 150.57 & 26198.50 \\
\hline & 50 to 65 years & 225 & 238.23 & 53601.50 \\
\hline & Total & 399 & & \\
\hline
\end{tabular}

older employees which cause additional strain resulting in emotional symptoms of burnout.

On average, older and younger employees are not exposed to behavioural symptoms of burnout. But on average, older employees neither agree nor disagree with the following: I lack the will to socialise with co-workers, I lack the will to work, I avoid activities, my working ability has declined, I have nightmares. Both, older and younger employees on average neither agree nor disagree with: I have insomnia. The same as physical and emotional symptoms of burnout in Slovenian companies, so are behavioural symptoms also caused by discrimination and stereotypes of age-diverse employees, workload in the workplace which includes long hours, work overload, time pressure, lots of job demands, difficult or complex tasks, over-demanding and inflexible work schedules, lack of breaks, lack of control over aspects of the job, lack of involvement in decision making, lack of variety and poor physical work conditions. Causes for symptoms of burnout can also result from lack of communication in the workplace and poor management. Lack of communication in the workplace can occur between management and employees and also between individual employees. Poor communication often leads to conflict, which can harm an organization. Poor management is reflected in an aggressive management style, bullying, lack of support of em- 
Table 10: Statistically significant differences in the behavioral symptoms of burnout between younger and older employees

\begin{tabular}{|c|c|c|}
\hline & Mann-Whitney U & Asymp. Sig. (2-tailed) \\
\hline vsi1: I have attacks of rage and cry. & 14747.000 & .000 \\
\hline vsi2: I avoid activities. & 15278.000 & .000 \\
\hline vsi3: I have nightmares. & 15379.500 & .000 \\
\hline vsi4: I have insomnia. & 17141.500 & .028 \\
\hline vsi5: I have difficulties with concentration and memory. & 8318.500 & .000 \\
\hline vsi6: I wish for solitude. & 9027.500 & .000 \\
\hline vsi7: My working ability has declined. & 8263.500 & .000 \\
\hline vsi8: I lack the will to work. & 13249.000 & .000 \\
\hline vsi9: I lack the will to socialise with co-workers. & 10973.500 & .000 \\
\hline
\end{tabular}

ployees from manager, lack of understanding and leadership, manager forever finding fault and poor relationships in the workplace.

The consequences of symptoms of burnout for the organization are high absenteeism, high presentism, high fluctuation, poor performance and productivity, increased ill-health, poor motivation and satisfaction in the workplace.

Therefore managers play an important role by reducing the workload on employees in the workplace. Managers should be aware of age of employees and their diverse needs. Slovenian companies should provide for their employees work hour flexibility (for example reduced hours, part-time work, job sharing), work schedule flexibility (for example flex schedule, annualized hours, compressed work week), flexibility of place (for example remote work), promoting health and a healthy lifestyle, promoting awareness of stress, stressors and solutions, promoting well-being and preventing stress in the workplace, managing stress and burnout in the workplace, relaxation training. Working conditions must be adapted to all employees and workplaces should be developed according to age diversity of employees and the workload adapted to all age groups. Organizational factors tend to play an important role in employees burnout and well-being. Therefore, Slovenian organizations should actively try to detect such factors and take corrective actions for the better health and well-being of the employee. It is important to know that job characteristics are not the same for age-diverse workers. In today's workplace, worker age would appear to be such an important individual difference. Managing diversity requires a strategic approach to manage people at work and is an important part of human resource management. From this perspective, this research shows the importance of well-being, health and friendly work environment for age-diverse employees and elimination of burnout symptoms in the Slovenian workplace. Age-diverse employees are faced with different symptoms of burnout when car- rying out their work. Therefore, this research adds to the body of knowledge by pointing out the relationships between the age and the burnout symptoms which have not been studied enough, because the role of age in job design and implementation of work have largely been ignored.

\section{Limitations and future research opportunities}

Our study is limited to the field of older and younger employees in Slovenian place. Limitation of this research is also reflected in the literature, because there is not much literature that comprehensively and systematically bases on theoretical knowledge and studies examining the management of older employees and management of age-diverse employees. Therefore, our proposal for further research is to examine the differences in burnout and coping with burnout in the workplace among younger and older employees between different countries. Further research possibilities include also the study relating to examination of the different measures that have been introduced in different countries for prevention of burnout in the workplace and their performance for an organization. Future studies could also investigate the effects of other antecedents (drivers) which would influence burnout.

\section{Literature}

Ahola, K., Honkonen, T., Isometsa, E., Kalimo, R., Nykyri, E., \& Koskinen, S. (2006). Burnout in the General Population: Results from the Finnish health 2000 study. Social Psychiatry and Psychiatric Epidemiology, 41 (1), 11-17. In Hertel G., van der Heijden B.I. J.M., de Lange A. H., \& Deller J. (2013b). Facilitating Age Diversity in Organizations - Part I: Challenging Popular Misbeliefs. Journal of Managerial Psychology, 28 (7/8), 729-740, http://dx.doi.org/10.1108/JMP- 
07-2013-0233

Ambrose, J., \& Norman Benson Wier, C.S. (2010). Healthy Lifestyle as a Coping Mechanism for Role Stress in Public Accounting. Behavioral Research in Accounting, 22, 21-41, http://dx.doi.org/10.2308/ bria.2010.22.1.21

Ashikali T., \& Groeneveld S. (2015). Diversity Management for All? An Empirical Analysis of Diversity Management Outcomes Across Groups. Personnel Review, 44 (5), 757-780, http://dx.doi.org/10.1108/ PR-10-2014-0216

Ashill, N. J., Rod, M., Thirkell, P., \& Carruthers, J. (2009). Job Resourcefulness, Symptoms of Burnout and Service Recovery Performance: An Examination of Call Centre Frontline Employees. Journal of Services Marketing, 23 (5), 338-350, http://dx.doi. org $/ 10.1108 / 08876040910973440$

Bastič, M. (2006). Metode raziskovanja [Research Methods]. Ekonomsko-poslovna fakulteta, Univerza v Mariboru.

Beaver, G., \& Hutchings, K. (2005). Training and Developing an Age Diverse Workforce in SMEs: The need for a strategic approach. Education + Training, 47 (8/9), 592604, http://dx.doi.org/10.1108/00400910510633134

Beata A. B., \& Izabela W., A. M. D. (2014). Fatigue and Burnout in Police Officers: The mediating role of emotions. Policing: An International Journal of Police Strategies \& Management, 37 (3), 665-680, http://dx.doi.org/10.1108/PIJPSM-10-2013-0105

Brandy K. L., \& Cox, G. O. (2002). Management of Occupational Stress. NY: Macmillan Publishers. In Babajide, E. O., \& Akintayo, I. (2011). Occupational Stress, Psychological Well Being and Workers Behavior in Manufacturing Industries in South-West Nigeria. International Journal of Management \& Innovation, 3 (1), 32-42, http://trove.nla.gov.au/version/172250455

Burke R. J, \& Greenglass E. R. (2001). Hospital Restructuring, Work-family Conflict and Psychological Burnout Among Nursing Staff. Psychol, Health. In Maslach, C., Schaufeli, W.B., \& Leiter, M.P. (2001). Job Burnout. Annual Review of Psychology, 52, 397422, https://www.ncbi.nlm.nih.gov/pubmed/22804500

Ellrich, K. (2016). Burnout and Violent Victimization in Police Officers: A dual process model. Policing: An International Journal of Police Strategies \& Management, 39 (4), 652-666, http://dx.doi.org/10.1108/ PIJPSM-10-2015-0125

Embriaco, N., Papazian, L., Kentish-Barnes, N., Pochard, F., \& Azoulay, E. (2007). Burnout Syndrome among Critical Care Healthcare Workers. Current opinion in critical care, 13 (5), 482-488, https://www.ncbi.nlm. nih.gov/pubmed/17762223

Fairbrother, K., \& Warn, J. (2003). Workplace Dimensions, Stress and Job Satisfaction. Journal of Managerial Psychology, 18 (1), 8-21, http://dx.doi. org/10.1108/02683940310459565
Fogarty, T. J., Singh, J., Rhoads, G. K., \& Moore R. K. (2000). Antecedents and Consequences of Burnout in Accounting: Beyond the role stress model. Behavioral Research in Accounting, 12, 31-68, http://ssrn.com/ab$\underline{\text { stract }=37387}$

George, E., \& Zakkariya K.A. (2015). Job Related Stress and Job Satisfaction: A comparative study among bank employees. Journal of Management Development, 34 (3), 316-329, http://dx.doi.org/10.1108/JMD-07-20130097

Grebner, S., Elfering, A., \& Semmer, N., K. (2010). The Success Resource Model of Job Stress. In: Perrewé, Pamela L., \& Ganster, Daniel C. (eds.) New Developments in Theoretical and Conceptual Approaches to Job Stress. Research in Occupational Stress and Well-being, 8, 61-108. Retrieved from https://books. google.si/books/about/New_Developments_in Theoretical_and_Conc.html?id=XrJsbnrfBY8C\&redir_es$\mathrm{c}=\mathrm{y}$

Halkos, G., \& Bousinakis, D. (2010). The Effect of Stress and Satisfaction on Productivity. International Journal of Productivity and Performance Management, 59 (5), 415-431, http://dx.doi. org/10.1108/17410401011052869

Hansson, R.O., Robson, S.M., \& Limas, M.J. (2001). Stress and Coping among Older Workers. Work, 17 (3), 24756, https://www.ncbi.nlm.nih.gov/pubmed/12441603

Henkens, K., \& Leenders, M. (2010). Burnout and Older Workers Intentions to Retire. International Journal of Manpower, 31 (3), 306-321, http://dx.doi. org $/ 10.1108 / 01437721011050594$

Hertel, G., van der Heijden, B.I.J.M., de Lange, A.H., \& Deller J. (2013b). Facilitating Age Diversity in Organizations - Part I: Challenging Popular Misbeliefs. Journal of Managerial Psychology, 28 (7/8), 729-740, http://dx.doi.org/10.1108/JMP-07-2013-0233

Hertel, G., van der Heijden, B.I.J.M., de Lange, A.H., \& Deller J. (2013a). Facilitating Age Diversity in Organizations - Part II: Managing Perceptions and Interactions. Journal of Managerial Psychology, 28 (7/8), 857-866, http://dx.doi.org/10.1108/JMP-07-20130234

Kristensen, T.S., Borritz, M., Villadsen, E., \& Christensen, K.B. (2005). The Copenhagen Burnout Inventory: A New Tool for the Assessment of Burnout. In Robinson, L.D., Megee, C., \& Caputi, P. (2016). Burnout and the Work-family Interface: A Two-wave Study of sole and partnered working mothers. Career Development International, 21 (1), 31-44, http://dx.doi. org/10.1108/CDI-06-2015-0085

Ilmarinen, J. (2001). Aging Workers. Occupational and Environmental Medicine, 58 (8), 546-552, https:// www.ncbi.nlm.nih.gov/pubmed/11452053

Intiyas Utami, S. C., \& Supriyadi, G. M. (2013). Flexible Working Arrangement and Stress Management Training in Mitigating Auditor's Burnout: An Experimental 
Study. Accounting \& Taxation, 5 (1), 97-113, https://papers.ssrn.com/sol3/papers.cfm?abstract id $=2270892$

Leiter, M.P., Frizzell, C., Harvie, P., \& Churchill, L. (2001). Abusive Interactions and Burnout: Examining Occupation, Gender, and the Mediating Role of Community. Psychology and Health, 16 (5), 547-63, http:// dx.doi.org/10.1080/08870440108405526

Lester, J. M., \& Brower K. L. (2001). Industrial psychology. NY: Macmillan Press Ltd.

Malik, O.F., Waheed, A., \& Malik, K.U.R. (2010). The Mediating Effects of Job Satisfaction on Role Stressors and Affective Commitment. International Journal of Business and Management, 5 (11), 223-235, http:// dx.doi.org/10.5539/ijbm.v5n11p

Maslach, C., Schaufeli, W.B., \& Leiter, M.P. (2001). Job Burnout. Annual Review of Psychology, 52, 397-422. Retrieved from http://www.wilmarschaufeli.nl/publications/Schaufeli/154.pdf

Michael, O., Court, D., \& Petal, P. (2009). Job Stress and Organizational Commitment among Mentoring Coordinators. International Journal of Educational Management, 23 (3), 266-288, http://dx.doi. org/10.1108/09513540910941766

Moore, J. (2000). One Road to Turnover: An Examination of Work Exhaustion in Technology Professionals. MIS Quarterly, 24 (1), 141-168, https://www.jstor.org/stable/3250982

Morgeson, F.P., \& Humphrey, S.E. (2006). The Work Design Questionnaire (WDQ): Developing and Validating a Comprehensive Measure for Assessing Job Design and the Nature of Work. Journal of Applied Psychology, 91 (6), 1321-1339, https://www.ncbi.nlm. nih.gov/pubmed/17100487

Mosadeghrad, A.M. (2014). Occupational Stress and its Consequences: Implications for Health Policy and Management. Leadership in Health Services, 27 (3), 224-239, http://dx.doi.org/10.1108/LHS-07-2013$\underline{0032}$

Nahrgang, J. D., Morgeson, F. P., \& Hofmann, D.A. (2011). Safety at Work: A Meta-analytic Investigation of the Link Between Job Demands, Job Resources, Burnout, Engagement, and Safety Outcomes. Journal of Applied Psychology, 96 (1), 71-94, https://www.ncbi.nlm.nih. gov/pubmed/21171732

Naegele, G., \& Walker, A. (2006). A Guide to Good Practice in Age Management. European Foundation for the Improvement of Living and Working Conditions, Office for Official Publications of the European Communities, Luxembourg, 1-35. Retrieved from http://www. ageingatwork.eu/resources/a-guide-to-good-practicein-age-management.pdf

Parkes, H. L. (2002). Human health and management. London: Macmillan Press Ltd.

Walker, A., \& Taylor, P. (1998). Combating Age Barriers in Employment: a European Portfolio of Good Practice, Office for Official Publications of the European Com- munities, Luxemburg. In Principi A., Fabbietti P., \& Lamura G. (2015). Perceived Qualities of Older Workers and Age Management in Companies: Does the Age of HR Managers Matter? Personnel Review, 44 (5), 801-820, http://dx.doi.org/10.1108/PR-09-2013-0158

Pruessner, J. C., Hellhammer, D. H., \& Kirschbaum, C. (1999). Burnout, Perceived Stress, and Cortisol Responses to Awakening. Psychosomatic medicine, 61 (2), 197-204, https://www.ncbi.nlm.nih.gov/pubmed/10204973

Rumbles, S., \& Rees G. (2013). Continuous Changes, Organizational Burnout and the Implications for HRD. Industrial and Commercial Training, 45 (4), pp. 236242, http://dx.doi.org/10.1108/00197851311323538

Shirom, A. (1989). Burnout in Work Organizations. International Review of Industrial and Organizational Psychology. New York: Wiley,

Suner-Soler, R., Grau-Martína, A., Flichtentrei, D., Prats M., Braga F., Font-Mayolas S., \& Gras, M.E. (2014). The Consequences of Burnout Syndrome among Healthcare Professionals in Spain and Spanish speaking Latin American countries. Burnout and HealthCare, 1 (2), pp. 82-89, http://dx.doi.org/10.1016/j. burn.2014.07.004

Swider, R.B.W., \& Zimmerman, Y.D. (2010). Born to Burnout: A Meta-analytic Path Model of Personality, Job Burnout, and Work Outcomes. Journal of Vocational Behavior, 76, 487-506, http://dx.doi.org/10.1016/j. jub.2010.01.003

Truxillo, D.M., Cadiz, D.M., Rineer, J.R., Zaniboni, S., \& Fraccaroli, F. (2012). A Lifespan Perspective on Job Design: Fitting the Worker to the Job to Promote Job Satisfaction, Engagement, and Performance. Organizational Psychology Review, 2 (4), 340-360. Retrieved from http://journals.sagepub.com/doi/ pdf $/ 10.1177 / 2041386612454043$

Yavas, U., Babakus, E., \& Karatepe, O.M. (2013). Does Hope Moderate the Impact of Job Burnout on Frontline Bank Employees In-role and Extra-role Performances? International Journal of Bank Marketing, 31 (1), 5670, http://dx.doi.org/10.1108/02652321311292056

Yunus, M.J., \& Mahajar, A. (2009). The Empirical Study of Burnout among Nurses of Publichospitals in the Northern Part of Malaysia. Journal of International Management Studies, 4 (3), 1-9. Retrieved from http:// citeseerx.ist.psu.edu/viewdoc/download;jsessionid=B656EC2B7DF348BBD4E6C3EADA2E7DF7?doi $=10.1 .1 .383 .8225 \& \mathrm{rep}=$ rep1\&type $=\mathrm{pdf}$

Zaniboni, S., Truxillo, D. M., Fraccaroli, F., McCune, E. A., \& Bertolino, M. (2014). Who Benefits from More Tasks? Older Versus Younger Workers. Managerial Psychology, 29 (5), 523-508, http://dx.doi. org/10.1108/JMP-12-2012-0381 
Maja Rožman studied at the Faculty of Economics and Business at the University of Maribor, and successfully graduated in Finance and Banking in 2011. In 2013, she acquired her master's degree and is currently working on her Ph.D. at the Faculty of Economics and Business in Maribor at the Department of Management and Organization.

Sonja Treven, Ph.D., Professor is employed at the School of Business and Economics at the University of Maribor, Slovenia. She researches in the field of human resource management and organisational behaviour. She is the Head of the Department of Management and Organisation. She is the author of 3 books and co-author of more than 20 books as well as more than eighty scientific articles. She participated in more than 100 domestic and international conferences with her papers as an author or co-author.
Vesna Čančer holds a Ph.D. in Economic and Business Sciences, and is an associate professor of quantitative methods in Business Science at the University of Maribor's Faculty of Economics and Business (UM FEB). Her research focuses primarily on decision analysis, creative problem solving, and research methods, together with their interdisciplinary applications. She is head of the Department of Quantitative Economic Analysis at UM FEB and editor-in-chief of a journal of contemporary issues in economics and business entitled Naše gospodarstvo / Our Economy.

Marijan Cingula, Ph.D., Professor is employed at the Faculty of Economics and Business Zagreb at the University of Zagreb in Croatia for the fields of organisational restructuring, business strategy as well as corporate management. He was the Head of the Department of organisation at the Faculty of organisation and informatics in Varaždin for some years. He is the author/coauthor of some books, manuals and great number of scientific papers. He also participated in many international and domestic conferences with his papers. 